\title{
Correlation between in hospital stay and EuroSCORE index
}

\author{
R Almeida*, M Centenaro \\ From 23rd World Congress of the World Society of Cardio-Thoracic Surgeons \\ Split, Croatia. 12-15 September 2013
}

\section{Background}

Time spent in the intensive care unit (ICU) and hospital are increasingly important when planning care for high complex diseases. The objective is to assess the feasibility of Euroscore as a predictor of length of stay.

\section{Methods}

In a retrospective cross-sectional study, October 2009/ 11, 65 patients were evaluated after CABG. Demographic data, time of $\mathrm{CPB}$, length in ICU and in hospital, were obtained. Patients were stratified into three groups, according to the EuroSCORE additive index: 0-2 (low risk), 3-5 (intermediate risk) and greater than 5 (high risk).

\section{Results}

Fifty two patients (80\%) were male; mean age was $62.20 \pm$ 9.51 years; mean body mass index was $28.01 \pm 4.16$. The additive EuroSCORE was $3.98 \pm 3.00$. The low-risk group represented $33.84 \%$, 38.46\% the intermediate and $27.69 \%$ the high risk. Average length of ICU stay was $3.03 \pm 4.38$ days and hospital $9.64 \pm 6.61$ days. Analyzing the group with long stay, $63.63 \%$ were female (OR $2.4095 \%$ CI 0.58 to $9.81 ; \mathrm{x} 20.71$, p: 0.39$), 81.81 \%$ were older than 60 years ( OR 0.34 95\% CI 0.12 to 2.15 ; x2 0.34, p: 0.55 ), $54.55 \%$ had a BMI> $25 \mathrm{~kg} / \mathrm{m} 2$ (OR $0.4095 \%$ CI 0.10 to 1,$53 ; \mathrm{x} 2$ 0.99 , p: 0.31$), 81.81 \%$ remained for more than 40 minutes on CPB (OR 0.09 95\% CI 0.00 to 1.14; x2 2.11, p: 0 14). In relation to risk stratification, had long stay: the lowrisk patients $9.09 \%$ (OR 0.35 95\% CI 0.06 to 1.81 ; x2 0.87 , p: 0.35 ), the risk intermediate $12.00 \%$ (OR $0.5195 \%$ CI 0.12 to $2.15 ; \mathrm{x} 20.34, \mathrm{p}: 0.53$ ) and $33.33 \%$ high risk (OR 5.04 95\% CI $1.27-19.88$; x2 4.25, p: 0.03).

\footnotetext{
* Correspondence: ruimslameida@iccop.com.br

Cardiovascular Surgery, Faculdade Assis Gurgacz, Cascavel, Brazil
}

\section{Conclusions}

The authors found correlation between the length of stay in ICU and hospital, with the Euroscore index, with statistical significance in the high risk group.

Published: 11 September 2013

doi:10.1186/1749-8090-8-S1-0164

Cite this article as: Almeida and Centenaro: Correlation between in hospital stay and EuroSCORE index. Journal of Cardiothoracic Surgery 2013 8(Suppl 1):0164.
Submit your next manuscript to BioMed Central and take full advantage of:

- Convenient online submission

- Thorough peer review

- No space constraints or color figure charges

- Immediate publication on acceptance

- Inclusion in PubMed, CAS, Scopus and Google Scholar

- Research which is freely available for redistribution
() Bïomed Central

\section{() Biomed Central}

